\title{
MODEL PENUNJANG KEPUTUSAN INVESTASI BAGI PENGEMBANGAN AGROINDUSTRI PERIKANAN
}

Oleh :

BAMBANG HERRY PURNOMO *)

\begin{abstract}
ABSTRAK
Investasi mempunyai peranan penting dalam menumbuhkembangkan agroindustri perikanan. Model penunjang keputusan investasi diperlukan dalam rangka membantu pemerintah daerah mengambil keputusan investasi agroindustri perikanan secara cepat dan tepat. Kajian ini bertujuan merancangbangun Sistem Manajemen Ahli untuk menunjang keputusan investasi dengan menggunakan pendekatan wilayah bagi pengembangan agroindustri perikanan dan kelembagaannya. Sistem terdiri dari 6 model, yaitu (1) fuzzy expert system untuk menentukan wilayah pengembangan, (2) model untuk menentukan komoditas perikanan unggulan, (3) model untuk menentukan produk unggulan, (4) model untuk menentukan potensi bahan baku, (5) model analisis kelayakan finansial proyek agroindustri, dan (6) model untuk menentukan bentuk kelembagaan bagi pengembangan usaha kecil perikanan. Verifikasi model dilakukan di Kabupaten Tuban, Jawa Timur. Contoh hasil verifikasi menunjukkan bahwa wilayah pengembangan yang terpilih adalah Kecamatan Palang dengan komoditas utamanya ikan teri dan produk unggulannya ikan teri asin. Potensi bahan baku ikan teri pada tahun 2010 yang dapat dimanfaatkan oleh proyek agroindustri di wilayah ini adalah 1067 ton. Kajian lebih lanjut yang disarankan adalah penggunaan model dinamis untuk menduga produksi ikan teri dan pengembangan interface model penunjang keputusan yang lebih fleksibel dan user friendly.
\end{abstract}

Kata kunci : investasi, model, sistem manajemen ahli (SMA), agroindustri perikanan. 


\section{PENDAHULUAN}

\section{Latar Belakang}

Merujuk pada definisi yang diberikan Austin (1992), maka agroindustri perikanan dapat diartikan sebagai industri yang mengolah komoditas hasil perikanan untuk meningkatkan nilai tambahnya. Menurut Resosudarmo et al (2003) optimalisasi usaha agroindustri perikanan dapat dicapai melalui pengembangan investasi industri perikanan mulai tingkat hulu sampai hilir.

Murillas dan Chamorro (2006) menyatakan bahwa investasi dibidang perikanan, termasuk agroindustri, mempunyai arti mengeluarkan modal pada saat ini untuk mendapatkan keuntungan dan manfaat dari suatu usaha perikanan di masa mendatang. Dalam konteks ini, maka perencanaan investasi agrondustri mempunyai arti merencanakan agroindustri pada suatu daerah untuk mendapatkan berbagai manfaat dan keuntungan bagi daerah tersebut pada masa mendatang.

Satria et al (2002) menyatakan bahwa seiring dengan lahirnya otonomi daerah yang dituangkan dalam UU Nomer 32 Tahun 2002, maka investasi agroindustri perikanan dapat dilaksanakan di daerah melalui kebijakan pemerintah daerah. Namun seperti yang dinyatakan oleh Fauzi (2002) sering kebijakan tersebut justru berujung pada ekploitasi sumberdaya. Pontecorvol dan Schrank (2001) menilai bahwa eksploitasi tersebut disebabkan karena faktor ekonomi tanpa mengindahkan keberlanjutan sunberdaya dan lingkungannya.

Sebagai perencana investasi, pemerintah daerah perlu mempertimbangkan berbagai aspek yang berkaitan dengan investasi, seperti aspek ekonomi, sosial dan lingkungan/ekologi (Prestes dan Petersen, 2004). Hal tersebut perlu dilakukan agar pengembangan agroindustri perikanan dapat berkelanjutan, artinya secara ekonomis efisien dan menguntungkan, secara ekologi sesuai dengan ketersediaan sumberdaya daya alamnya dan ramah lingkungan serta secara sosial berkeadilan (Harris, 2001).

Sehubungan dengan hal tersebut, Harta dan Barton (2007) menyatakan bahwa diperlukan kebijakan pemerintah dalam mengatur tingkat investasi dan tingkat penggunaan sumberdaya yang selama ini terjadi agar sumberdaya dan aktivitas ekonomi masyarakat dapat terus berlangsung. Robert et al (2005) menambahkan bahwa kebijakan yang dapat diambil oleh pemerintah adalah menjaga ketersediaan sumberdaya perikanan agar dapat digunakan secara bersama dan berkelanjutan. Hal ini karena keberlangsungan investasi agroindustri perikanan dan usaha perikanan masyarakat atau agroindustri skala kecil tergantung sepenuhnya terhadap bahan baku sumberdaya perikanan.

Oleh karena itu, Mardle dan Pascoe (2002) menilai bahwa kebijakan pengaturan skala industri perikanan berdasarkan ketersediaan sumberdayanya sangat diperlukan agar selalu terjadi keberlanjutan. Atau dalam arti lain jangan sampai adanya investasi agroindustri perikanan justru mematikan agroindustri perikanan kecil yang menjadi sumber kehidupan bagi masyarakat. Dengan demikian kebijakan investasi pemerintah harus mencakup 2 hal, yaitu terwujudnya keberlanjutan usaha dan sumberdaya perikanan yang nantinya akan berdampak pada pemberdayaan ekonomi masyarakat (Hartono dan Nasution, 2005).

Dalam perencanaan investasi, kebijakan pemerintah untuk menentukan wilayah dimana investasi tersebut akan dilakukan, merupakan keputusan yang bersifat strategis. Menurut Dahuri (2003) setiap wilayah mempunyai kekhususan dalam sumberdaya perikanan, sehingga berdasarkan hal tersebut jenis investasi agroindustri yang dilakukan pada suatu wilayah dapat berbeda-beda, tergantung dari potensi perikanannya. Oleh karena itu, pendekatan yang diyakini sesuai untuk digunakan dalam perumusan keputusan investasi adalah pendekatan wilayah. Penggunaan pendekatan wilayah dalam pengembangan agroindustri perikanan sesuai dengan kebijakan yang diamanatkan oleh BAPPENAS (2004) dan DKP (2004).

Untuk membantu para pengambil keputusan, dalam hal ini pemerintah daerah, menilai secara tepat keputusan investasi agroindustri perikanan diwilayahnya, maka diperlukan alat bantu penunjang keputusan investasi. Dalam kajian ini dikembangkan model Sistem Manajemen Ahli untuk membantu menunjang keputusan investasi agroindustri. Verifikasi kajian dilakukan di Kabupaten Tuban, salah satu wilayah di Jawa Timur yang mempunyai sumberdaya perikanan yang potensial, untuk menilai investasi agroindustri perikanan apa yang layak dikembangkan di daerah tersebut.

\section{Tujuan}

Tujuan kajian ini adalah menghasilkan Sistem Manajemen Ahli untuk menunjang keputusan investasi dengan menggunakan pendekatan wilayah bagi pengembangan agroindustri perikanan dan kelembagaannya. 


\section{Ruang Lingkup}

Ruang lingkup kajian ini adalah :

a. Obyek kajian adalah agroindustri perikanan yang berbasis komoditas hasil laut.

b. Wilayah pengembangan untuk investasi agroindustri perikanan adalah daerah sesuai batas administrasi wilayah kabupaten.

c. Model yang dikembangkan digunakan untuk mengambil keputusan investasi agroindustri perikanan di wilayah kabupaten.

\section{Sistematika Penulisan}

Paper ini terdiri dari 6 bagian. Bagian pertama berisi latar belakang, tujuan dan ruang lingkup kajian. Bagian kedua adalah tinjauan pustaka yang memuat landasan teori. Bagian berikutnya adalah metodologi yang memuat kerangka pemikiran dan tata laksana kajian. Bagian keempat adalah perancangan model yang berisi tahap perancangan dengan pendekatan sistem. Bagian kelima adalah hasil dan pembahasan yang berisi verifikasi model. Bagian terakhir adalah kesimpulan dan saran.

\section{TINJAUAN PUSTAKA}

\section{Sistem Manajemen Ahli (Expert Management System)}

Sistem Manajemen Ahli (SMA) merupakan alat bantu pengambilan keputusan bagi manajer untuk menyelesaikan masalah yang sangat kompleks. SMA merupakan pengembangan dari Sistem Pendukung Keputusan (SPK). Pengertian SPK menurut Turban (1993) adalah sistem komputerisasi informasi yang menggunakan aturan keputusan dan model-model yang diakomodasikan dengan basis data. Struktur dasar SPK terdiri dari dua basis informasi, yaitu manajemen basis data dan manajemen basis model. Sedangkan pengertian Sistem Pakar menurut Marimin (2005) adalah perangkat lunak komputer yang menggunakan pengetahuan, fakta dan teknik inferensi untuk masalah yang biasanya membutuhkan kemampuan seorang ahli. Sistem Pakar merupakan salah satu bagian dari kecerdasan buatan. Turban (1993) menjelaskan bahwa SMA merupakan integrasi antara SPK dengan Sistem Pakar (Expert System). Integrasi tersebut dapat berupa menyatukan Sistem Pakar ke dalam komponenkomponen SPK atau membuatnya secara terpisah. Integrasi Sistem Pakar pada SPK dapat dilakukan pada basis data, basis model, sistem dialog, maupun rekayasa sistem dan pengguna.

SMA terdiri dari tiga basis sumberdaya informasi, yaitu Sistem Manajemen Basis Data (Data Base Management System), Sistem Manajemen Basis Model (Model Base Management System) dan Sistem Manajemen Basis Pengetahuan (Knowledge Base Management System). Ketiga basis informasi tersebut diolah dalam unit pemrosesan terpusat yang menerima masukan dari manajemen dialog (Eriyatno, 1999). Struktur Sistem Manajemen Ahli dapat dilihat pada Gambar 1.

Pada model yang dikembangkan, Sistem Pakar diintegrasikan dengan teknik penalaran fuzzy untuk menentukan wilayah pengembangan agroindustri. Pengetahuan pakar dimanfaatkan dalam bentuk aturan (rules). Metode yang digunakan dalam menganalisis pengambilan keputusan berdasarkan rules tersebut adalah Fuzzy Expert System. Sistem Pakar fuzzy (Fuzzy Expert System) merupakan penerapan sistem fuzzy dalam sistem pakar untuk mereprensentasikan pengetahuan pada lingkungan yang tidak pasti dan tidak lengkap serta sangat kompleks. Sistem tersebut merupakan pengembangan sistem pakar yang menggunakan logika fuzzy secara keseluruhan, yang meliputi gugus fuzzy, aturan if-then, serta proses inferensi (Marimin, 2005).

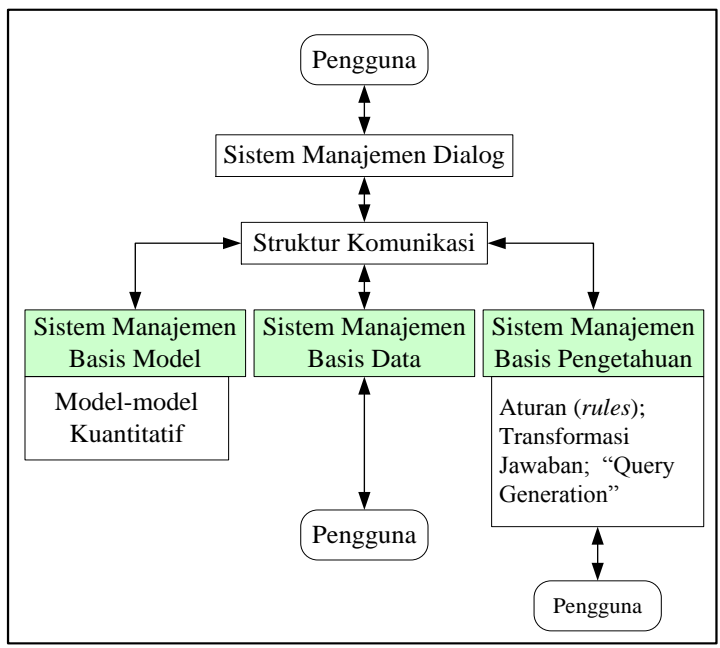

Gambar 1 Struktur Sistem Manajemen Ahli

\section{Pendekatan Wilayah dalam Investasi Agroindustri}

Menurut Undang-Undang Republik Indonesia Nomor 24 Tahun 1992 wilayah adalah ruang yang merupakan kesatuan geografis segenap unsur yang terkait padanya yang batas dan sistemnya ditentukan berdasarkan aspek administratif dan atau aspek fungsional. Pendekatan wilayah merupakan cara berfikir yang 
selalu memandang keterpaduan antara wilayah dengan obyek yang dikaji sebagai pijakan dalam merumuskan sistem pengelolaan atas obyek tersebut.

Rustiadi et al (2003) menjelaskan bahwa pendekatan wilayah melandaskan atas pemahaman karakteristik dan fenomena wilayah yaitu keterkaitan berbagai unsur yang terdapat didalamnya sebagai dasar dalam merumuskan dan penyusunan kebijakannya. Dengan demikian pada pendekatan tersebut, aspek kewilayahan selalu dijadikan titik tolak dalam menyelesaikan setiap permasalahan.

Menurut Hanafiah (1998) kebijakan pembangunan yang berdasar pada aspek kewilayahan perlu diawali dengan identifikasi dan analisis sumberdaya wilayah serta tujuan pemanfaatannya dengan selalu memperhatikan dampak yang ditimbulkan akibat pembangunan tersebut. Hal ini berarti bahwa sebelum kegiatan pembangunan dilaksanakan, maka langkah awalnya adalah melakukan penataan ruang untuk menetapkan wilayah yang sesuai bagi setiap jenis aktivitas pembangunan dalam rangka meminimalisasi dampak negatif dan mencegah pemborosan sumberdaya wilayah.

Bodie et al (2005) dan Kadariah (1986) menyatakan bahwa investasi adalah menanamkan modal dan menggunakan sumber daya dengan tujuan untuk mendapatkan keuntungan dan manfaat di masa mendatang. Menurut Kementrian Kelautan dan Perikanan (2004) kebijakan investasi perikanan tertuang dalam Peraturan Pemerintah Nomer 54 Tahun 2004 tentang Bisnis Perikanan. Bisnis perikanan adalah entitas bisnis privat atau legal untuk menangkap dan membudidayakan ikan termasuk upaya peyimpanan, pembekuan dan pengawetan untuk maksud komersial.

Kusumastanto (1994) menjelaskan bahwa investasi agroindustri berperan dalam menstimulasi pertumbuhan perekonomian di suatu daerah. Salah satu faktor kunci untuk mencapai keberhasilan investasi agroindustri adalah ketepatan dalam perencanaan investasi. Agar tujuan investasi tercapai, maka wilayah dimana investasi tersebut akan dilakukan haruslah mempunyai sumberdaya yang mendukung bagi pencapaian tujuan investasi. Bertolak dari konsepsi tersebut maka investasi agroindustri perikanan diyakini sesuai jika dikembangkan dengan pendekatan wilayah. Berbeda dengan investasi kebanyakan industri yang semata-mata hanya bertujuan memaksimalkan aspek ekonomi saja, maka dengan menggunakan filosofi pendekatan wilayah, tujuan pengembangan dan investasi agroindustri perikanan bukan hanya mengoptimalkan aspek finansial dan ekonomi, namun tetap mempertimbangkan keberlanjutan sumberdaya.

\section{METODOLOGI}

\section{Kerangka Pemikiran}

Kajian ini didasari atas pemikiran bagaimana membangun model penunjang investasi yang dapat menjaga keberlanjutan sumberdaya perikanan sehingga memberi manfaat yang maksimal bagi investor agroindustri, masyarakat pelaku usaha perikanan skala kecil dan pemerintah daerah. Dalam mewujudkan hal tersebut maka terdapat enam tahapan yang akan dilakukan dalam kajian ini (Gambar 2), yaitu pemilihan wilayah pengembangan, penentuan komoditas dan produk unggulan, analisis potensi bahan baku komoditas unggulan, analisis kelayakan finansial dan penentuan kelembagaan usaha bagi usaha perikanan skala kecil.

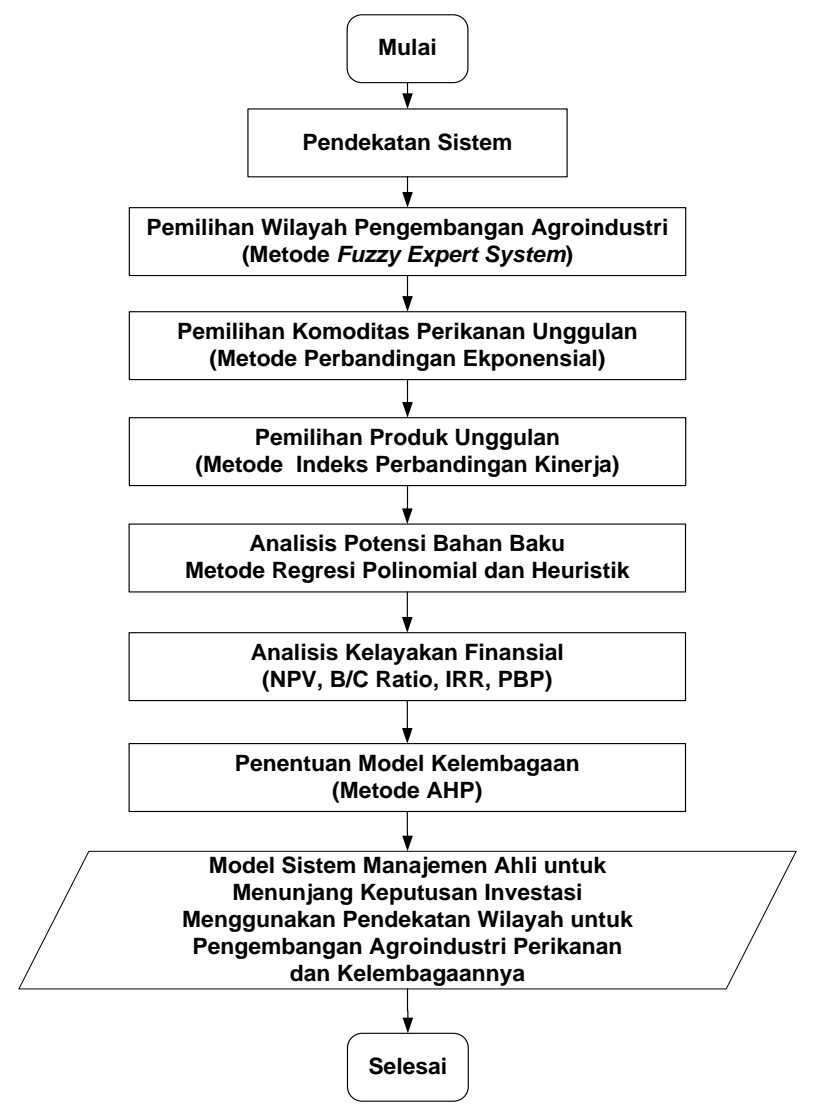

Gambar 2. Diagram alir tahapan kajian 


\section{Identifikasi Sistem}

Setelah kebutuhan setiap pelaku sistem diidentifikasi dan ditetapkan serta formulasi permasalahan ditentukan, maka selanjutnya dibangun diagram input-output sebagai dasar dalam merancang model SMA. Diagram input-output model ditunjukkan pada Gambar 3.

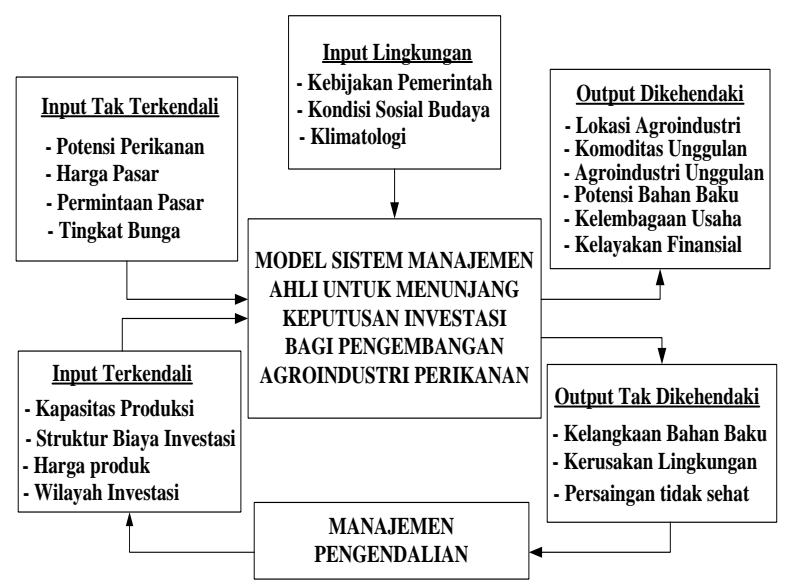

Gambar 3. Diagram input - output

Dalam diagram input-output, keluaran model yang akan dibangun ditunjukkan oleh output dikehendaki, sedangkan masukan model direpresentasikan oleh input terkendali. Output tak terkendali adalah dampak buruk akibat kinerja sistem. Selanjutnya, keluaran ini menjadi input bagi perekayasaan input terkendali melalui manajemen pengendalian.

\section{Konfigurasi Model}

Konfigurasi model SMA yang dibangun ditunjukkan pada Gambar 4. Konfigurasi model pada sistem ini terdiri dari manajemen basis data, manajemen basis model, manajemen basis pengetahuan, sistem pengolahan terpusat dan sistem dialog. Data-data yang digunakan untuk perhitungan model disimpan pada manajemen basis data, data pakar disimpan pada manajemen basis pengetahuan, sedangkan sub-sub model disimpan pada manajemen basis model. Kedua manajemen ini terhubung melalui sistem pengolahan terpusat. Sistem ini menerima perintah dari manajemen dialog untuk melakukan proses kalkulasi sebagaimana perintah pengguna.

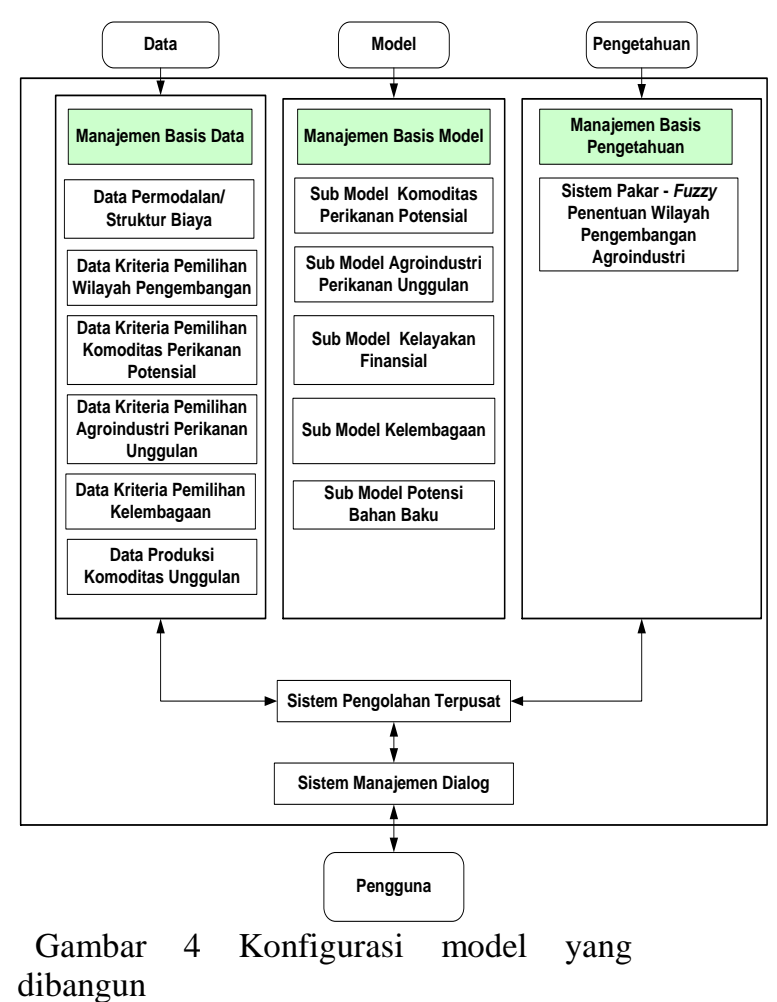

Tabel 1 Kisaran nilai numerik setiap variabel linguistik

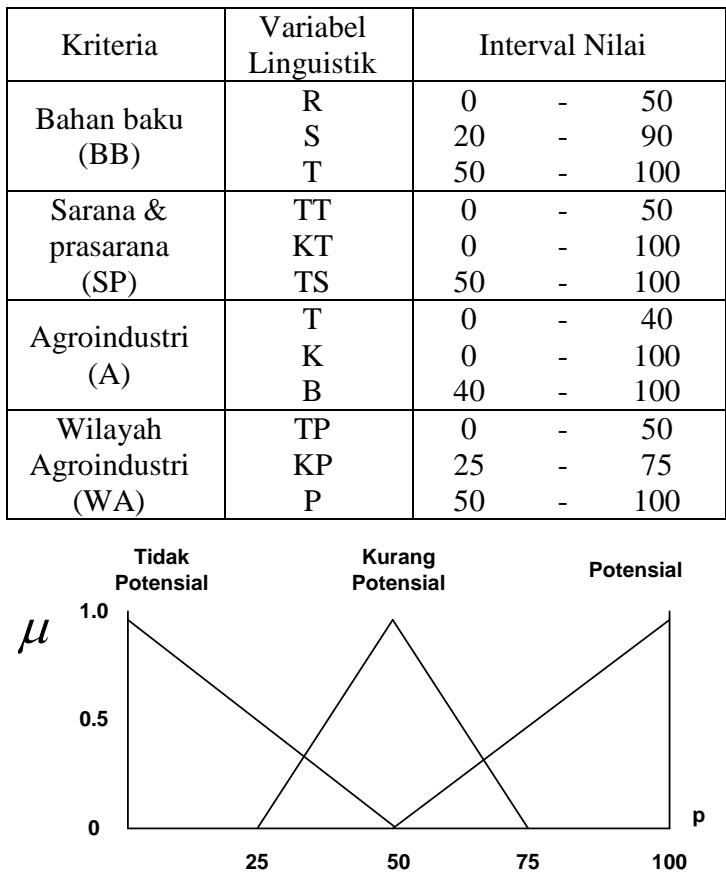

Gambar 6 Representasi variabel wilayah agroindustri dengan model TFN

Berdasarkan konsultasi pakar, maka dikembangkan aturan untuk proses inferensi. Aturan yang dikembangkan 
berjumlah 5 aturan, sebagaimana ditunjukkan pada Tabel 2.

Tabel 2. Aturan pakar untuk proses inferensi

\begin{tabular}{|c|c|c|c|c|}
\hline \multicolumn{4}{|c|}{ Anteseden } & \multirow{2}{*}{$\begin{array}{l}\text { Konsekuen } \\
\mathrm{WA}=\mathrm{TP}\end{array}$} \\
\hline IF & $\mathrm{BB}=\mathrm{R}$ & & THEN & \\
\hline IF & $\mathrm{SP}=\mathrm{TT}$ & & THEN & $\mathrm{WA}=\mathrm{TP}$ \\
\hline IF & $\begin{array}{l}\mathrm{BB}=\mathrm{T} \\
\mathrm{SP}=\mathrm{TS}\end{array}$ & AND & THEN & $\mathrm{WA}=\mathrm{P}$ \\
\hline IF & $\begin{array}{l}\mathrm{BB}=\mathrm{S} \\
\mathrm{SP}=\mathrm{KT}\end{array}$ & AND & THEN & $\mathrm{WA}=\mathrm{KP}$ \\
\hline IF & $\begin{array}{l}\mathrm{BB}=\mathrm{T} \\
\mathrm{SP}=\mathrm{KT}\end{array}$ & AND & THEN & $\mathrm{WA}=\mathrm{P}$ \\
\hline
\end{tabular}

Metode penalaran yang digunakan adalah MAMDANI, dengan fungsi implikasi MIN, metode agregasi MAX dan defuzzifikasi menggunakan metode centroid.

\section{Sub Model Komoditas Perikanan Unggulan}

Sub model ini bertujuan untuk menentukan komoditas perikanan unggulan di wilayah terpilih. Metode yang digunakan pada sub model ini adalah Metode Perbandingan Eksponensial (MPE) yang kemudian dikembangkan dengan menggunakan spreadsheet Microsoft Excel. Berdasarkan rujukan pustaka dan konsultasi pakar, maka ditetapkan 5 kriteria pemilihan komoditas unggulan, yaitu 1) Nilai ekonomis; 2) Basis agroindustri; 3) Bahan baku; 4) Peluang produksi; dan 5) Diversifikasi. Bobot kriteria ditentukan dengan metode perbandingan berpasangan (pairwise comparison). Selanjutnya ditentukan skornya dengan menggunakan persamaan berikut ini. komoditas yang mempunyai skor tertinggi sebagai komoditas unggulan

Total nilai $\left(\mathrm{TN}_{\mathrm{i}}\right)=\sum_{j=1}^{m}\left(R K_{i j}\right)^{T K K j}$

dimana :

\begin{tabular}{|c|c|c|}
\hline $\mathrm{TN}_{\mathrm{i}}$ & $=$ & Total nilai alternatif ke-i \\
\hline $\mathrm{RK}_{\mathrm{ij}}$ & $=$ & $\begin{array}{l}\text { Derajat kepentingan relatif kriteria } \\
\text { ke-j pada pilihan keputusan i }\end{array}$ \\
\hline $\mathrm{TKK}_{\mathrm{j}}$ & $=$ & $\begin{array}{l}\text { Derajat kepentingan kriteria } \\
\text { keputusan ke-j; } \mathrm{TKK}_{\mathrm{j}}>0 \text {; bulat }\end{array}$ \\
\hline & $=$ & Jumlah pilihan keputusan \\
\hline & $=$ & Jumlah kriteria keputusan \\
\hline
\end{tabular}

Marimin (2004)

\section{Sub Model Produk Unggulan}

Sub model ini bertujuan untuk menentukan agroindustri unggulan berbasis komoditas unggulan untuk dikembangkan pada wilayah pengembangan yang terpilih. Metode yang digunakan pada sub model ini adalah metode Indeks Perbandingan Kinerja (CPI). Program komputer yang digunakan dalam sub model ini adalah spreadsheet Microsoft Excel. Untuk memilih alternatif produk unggulan, maka ditetapkan 5 kriteria, yaitu 1) Peluang Pasar; 2) Resiko Produk; 3) Teknologi; 4) B/C ratio; dan 5) Dampak Ganda. Bobot kriteria ditentukan dengan metode perbandingan berpasangan (pairwise comparison). Penilaian dilakukan oleh narasumber ahli dengan menggunakan skala numerik antara 0 sampai 10 . Khusus nilai $\mathrm{B} / \mathrm{C}$ nilainya ditetapkan berdasarkan kajian pustaka dan bukan berbentuk nilai skor. Selanjutnya adalah melakukan konversi nilai dengan prinsip Comparative Performance Indeks (CPI). Caranya adalah dengan mengkonversi nilai penilaian terkecil dari setiap kriteria dengan nilai 100. Kemudian nilai-nilai lainnya dikonversikan menggunakan basis nilai terkecil dikalikan 100. Formula untuk konversi nilai-nilai kriteria dan penentuan skor alternatif ditunjukkan oleh persamaan berikut ini:

$\begin{array}{ll}\mathrm{A}_{\mathrm{ij}} & =\mathrm{X}_{\mathrm{ij}}(\min ) \times 100 / \mathrm{X}_{\mathrm{ij}}(\min ) \\ \mathrm{A}_{(\mathrm{i}+1 . \mathrm{j})} & =\left(\mathrm{X}_{(1+1 . \mathrm{j})}\right) / \mathrm{X}_{\mathrm{ij}}(\min ) \times 100 \\ \mathrm{I}_{\mathrm{ij}} & =\mathrm{A}_{\mathrm{ij}} \times \mathrm{P}_{\mathrm{j}} \\ \mathrm{I}_{\mathrm{i}} & =\sum_{i=1}^{n}\left(I_{i j}\right) \\ \text { dimana : } & \\ \mathrm{A}_{\mathrm{ij}} & =\text { Nilai alternatif ke-I kriteria ke-j } \\ \mathrm{X}_{\mathrm{ij}}(\mathrm{min}) & =\text { Nilai alternatif ke-i kriteria awal } \\ \mathrm{A}_{(\mathrm{i}+1 . \mathrm{j})} & =\text { Ninimum ke-j } \\ \mathrm{X}_{(\mathrm{i}+1 . \mathrm{j})} & =\text { Nilai alternatif ke-i+1 kriteria ke- } \mathrm{j} \\ \mathrm{P}_{\mathrm{j}} & =\text { Bobot kepentingan kriteria ke- } \mathrm{j} \\ \mathrm{I}_{\mathrm{ij}} & =\text { Indeks alternatif ke-i } \\ \mathrm{I}_{\mathrm{i}} & =\text { Indeks gabungan alternatif ke-i }\end{array}$

Marimin (2004)

\section{Sub Model Potensi Bahan Baku}

Sub model ini bertujuan untuk menentukan potensi bahan baku komoditas unggulan. Penentuan potensi diawali dengan memperkirakan jumlah bahan baku menggunakan teknik regresi polinomial berderajat 3 dan 4. Hasil prakiraan selanjutnya digunakan untuk menentukan potensi bahan baku dengan pendekatan heuristik.

\section{Prakiraan jumlah bahan baku}

Teknik yang digunakan dalam memperkirakan jumlah bahan baku adalah regresi polinomial. Bentuk umum regresi polinomial adalah sebagai berikut:

$$
Y=\beta_{o}+\beta_{1} X+\beta_{2} X^{2}+\ldots+\beta_{r} X^{r}
$$

Notasi X merupakan variabel bebas dan $\mathrm{Y}$ adalah variabel tidak bebas. Dalam 
model regresi polinomial yang akan digunakan, variabel $\mathrm{Y}$ adalah hasil perkiraan bahan baku dan $\mathrm{X}$ adalah variabel waktu. Notasi $\beta_{o}, \beta_{1} \ldots \beta_{r}$ merupakan nilai koefisien yang diestimasi dengan menggunakan metode Least square polinomial (Montgomery, 1991).

\section{Penentuan potensi bahan baku}

Potensi bahan baku dapat ditentukan jika prakiraan bahan baku telah diketahui. Selain itu komponen lain yang harus diketahui adalah jumlah agroindustri skala kecil yang menggunakan bahan baku tersebut serta kapasitas produksi rata-rata dari agroindustri tersebut. Untuk menentukan potensi bahan baku maka digunakan persamaan sebagaimana berikut ini:

$$
\begin{aligned}
& \text { TotJP }=\sum_{i=1}^{n} J P_{i} \quad i=1,2,3 \ldots, n \\
& \text { TotJA }=\sum_{p=1}^{r} J A_{p} \quad p=1,2,3, \ldots, r \\
& \text { Pot }=\text { TotJP }-(\text { TotJA } * \text { Kap })
\end{aligned}
$$

dimana;

$$
\begin{aligned}
\text { TotJP }= & \text { Produksi komoditas unggulan dari } \\
& \text { wilayah-wilayah yang ditetapkan. } \\
\text { TotJA = } & \text { Jumlah agroindustri skala kecil yang } \\
& \text { menggunakan basis komoditas yang sama } \\
& \text { dengan proyek agroindustri yang akan } \\
& \text { diinvestasikan. } \\
= & \text { Potensi bahan baku } \\
\text { Pot } & \text { Kapasitas produksi rata-rata agroindustri } \\
\text { Kap } & \text { kecil } \\
i= & \text { Wilayah menghasilkan bahan baku } \\
p \quad= & \text { jumlah agroindustri skala kecil }
\end{aligned}
$$

Apabila kapasitas produksi dari proyek agroindustri diketahui maka dapat ditentukan jumlah agroindustri yang diperlu diinvestasikan (dibangun) pada wilayah tersebut, atau sebaliknya justru tidak perlu untuk melakukan investasi pada wilayah tersebut karena bahan baku yang tidak mencukupi.

$$
\begin{aligned}
& \text { IF } K p \leq P o t \text { THEN } J P B=\frac{P o t}{K p} \\
& \text { IF } \quad K p \geq P o t \text { THEN } J P B=0 \\
& \text { dimana; }
\end{aligned}
$$

$$
\begin{array}{ll}
K p \quad=\quad \begin{array}{l}
\text { Kapasitas produksi dari proyek } \\
\text { agroindustri }
\end{array} \\
J P B \quad=\quad \begin{array}{l}
\text { Jumlah proyek agroindustri yang } \\
\text { dibangun pada wilayah terpilih }
\end{array}
\end{array}
$$

\section{Sub Model Kelayakan Finansial}

Sub model ini bertujuan untuk menilai kelayakan finansial proyek agroindustri yang akan dikembangkan. Kriteria finansial yang digunakan untuk menilai kelayakan agroindustri adalah Net Present Value (NPV), Internal Rate of Return (IRR), Net Benefit Cost
Ratio (B/C Ratio) dan Pay Back Period (PBP). Deskripsi dan persamaan matematis kriteria-kriteria tersebut dijelaskan sebagai berikut :

NPV = Merupakan perbedaan antara nilai sekarang (present value) dari manfaat dan biaya. Jika NPV positif, maka investasi layak dilakukan.

IRR = Merupakan suatu tingkat pengembalian modal yang digunakan dalam suatu proyek. Apabila nilai IRR > dari Discount Factor, maka investasi layak dilakukan

$\mathrm{B} / \mathrm{C}=$ Merupakan perbandingan seluruh ratio keuntungan dengan total biaya selama tahun proyek. Jika B/C > 1, maka investasi layak dilakukan

PBP = Menunjukan periode yang diperlukan untuk menutup kembali investasi dengan menggunakan aliran kas bersih

$$
N P V=\sum_{t=0}^{n} \frac{B_{t}-C_{t}}{(1+i)^{t}}
$$

dimana :

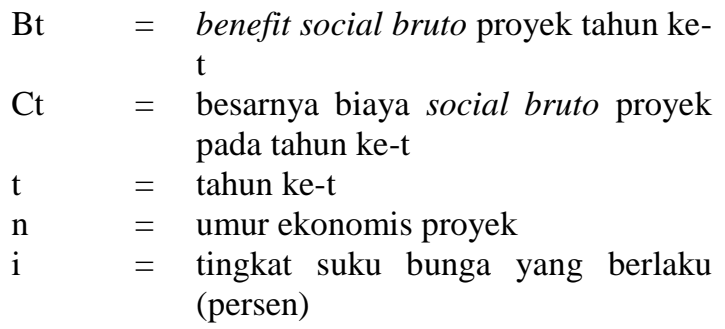

$$
I R R=i_{1}+\frac{N P V_{1}}{\left(N P V_{1}-N P V_{2}\right)} \times\left(i_{2}-i_{1}\right)
$$

dimana;

$$
\begin{aligned}
& \mathrm{NPV}_{1}=\text { NPV pada suku bunga } \mathrm{i}_{1} \\
& \mathrm{NPV}_{2}=\text { NPV pada suku bunga } \mathrm{i}_{2} \\
& \mathrm{i}_{1} \quad=\text { nilai } \mathrm{i} \text { dengan NPV bernilai positif } \\
& \mathrm{i}_{2} \quad=\text { nilai } \mathrm{i} \text { dengan NPV bernilai negatif } \\
& \text { Net } \mathrm{B} / \mathrm{C}=\frac{\sum_{t=0}^{n} \frac{B_{t}-C_{t}}{(1+i)^{t}}}{\sum_{t=0}^{n} \frac{C_{t}-B_{t}}{(1+i)^{t}}} \\
& P B P=\frac{\text { Investasiawal }}{\text { Aliran kas bersih }}
\end{aligned}
$$

Analisa sensitivitas digunakan untuk menilai seberapa jauh perubahan suatu parameter terhadap keputusan kelayakan investasi. Analisa ini dilakukan karena 
semua parameter proyek mempunyai ketidakpastian, apalagi untuk proyek-proyek yang mempunyai umur yang panjang.

(Gittinger JP. 1986)

\section{Sub Model Wilayah PengembanganAgroindustri}

Keluaran dari sub model ini adalah wilayah yang potensial bagi investasi agroindustri perikanan di wilayah kabupaten. Dalam studi kasus di Kabupaten Tuban, pemilihan wilayah dilakukan disejumlah wilayah kecamatan. yang mempunyai potensi perikanan hasil laut, yaitu kecamatan Palang, Tuban, Jenu, Tambakboyo dan Bancar. Kriteria pemilihan yang digunakan tercantum pada Tabel 3 .

Tabel 3 Kriteria pemilihan wilayah

\begin{tabular}{|c|c|}
\hline Kriteria & Deskripsi \\
\hline Bahan baku & $\begin{array}{l}\text { Jumlah produksi hasil perikanan } \\
\text { agregat suatu wilayah dan } \\
\text { kontinuitas penyediaannya }\end{array}$ \\
\hline $\begin{array}{l}\text { Sarana dan } \\
\text { prasarana }\end{array}$ & $\begin{array}{l}\text { Ketersediaan sarana dan prasarana } \\
\text { yang dimiliki suatu wilayah, seperti } \\
\text { fasilitas jalan transportasi, } \\
\text { pendaratan ikan, utilitas (air, listrik, } \\
\text { telepon) }\end{array}$ \\
\hline Agroindustri & $\begin{array}{l}\text { Jumlah dan perkembangan } \\
\text { agroindustri perikanan milik } \\
\text { masyarakat yang terdapat pada suatu } \\
\text { wilayah }\end{array}$ \\
\hline
\end{tabular}

Fuzzy expert system dikembangkan dengan menggunakan Tool Box Matlab 6.0. Input dari aplikasi tersebut adalah nilai numerik dengan skala 0 sampai 100 untuk masing-masing kriteria. Demikian juga output dari aplikasi merupakan nilai numerik dengan interval yang sama. Semakin tinggi nilai yang diberikan, maka semakin tinggi pula nilai dari output yang berarti semakin tinggi pula potensi suatu wilayah untuk dipilih. Aplikasi Tool Box Matlab untuk sub model pemilihan wilayah ditunjukkan pada Gambar 7.

Pemilihan wilayah pengembangan agroindustri di Kabupaten Tuban dilakukan dengan meminta penilaian narasumber ahli yang berasal dari instansi pemerintah. Pendapat kedua narasumber tersebut selanjutnya dilakukan rata-rata secara geometrik dan hasilnya digunakan sebagai masukan model. Hasil penilaian dan keluaran model ditunjukkan pada Tabel 4.

Wilayah yang paling potensial untuk dijadikan sebagai wilayah pengembangan adalah Kecamatan Palang dengan nilai 73.2, sedangkan Kecamatan Tuban mempunyai nilai terendah 45.7. Apabila dilihat dari nilai numeriknya, maka Kecamatan Tuban adalah wilayah yang paling tidak potensial dibanding wilayah lainnya. Namun berdasarkan representasi wilayah yang dibangun dengan logika fuzzy, Kecamatan Tuban mempunyai predikat yang sama dengan Kecamatan Jenu, Bancar dan Tambokboyo, dinyatakan kurang potensial.
Tabel 4 Hasil penilaian dan keluaran model

\begin{tabular}{|l|c|c|c|c|c|}
\hline \multirow{2}{*}{ Wilayah } & \multicolumn{3}{|c|}{ Input } & \multicolumn{2}{c|}{ Keluaran Model } \\
\cline { 2 - 6 } & Bahan Baku & Sarana & Agroindustri & Nilai & Linguistik \\
\hline & & & & & \\
Jenu & 59.79 & 62.45 & 46.90 & 54.4 & Kurang Potensial \\
Tuban & 44.72 & 72.46 & 64.23 & 45.7 & Kurang Potensial \\
Palang & 82.46 & 77.46 & 79.84 & 73.2 & Potensial \\
Tambak Boyo & 75.00 & 74.83 & 70.00 & 68.5 & Kurang Potensial \\
Bancar & 77.14 & 82.46 & 69.82 & 68.5 & Kurang Potensial \\
\hline
\end{tabular}

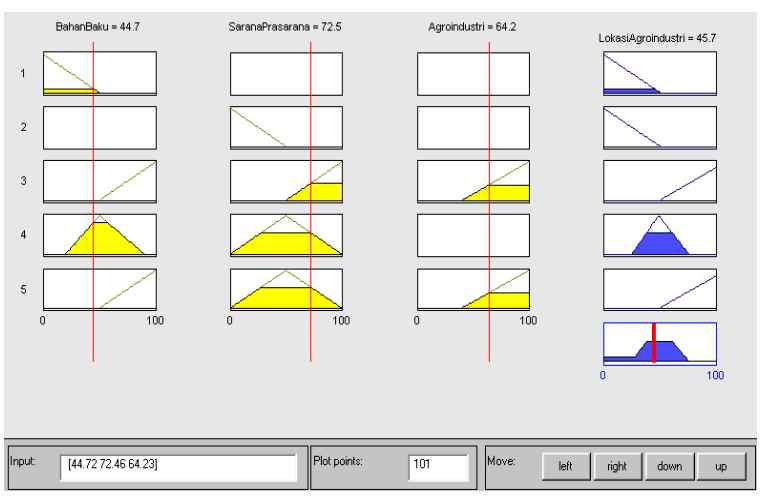

Gambar 7 Aplikasi Tool Box Matlab

\section{Sub Model Komoditas Perikanan Unggulan}

Alternatif komoditas yang dipilih terdiri dari empat jenis komoditas, yaitu 1) ikan Tembang; 2) ikan Teri; 3) Rebon; dan 4) Rajungan. Penentuan alternatif tersebut didasarkan atas jumlah produksi dan nilai ekonomis komoditas. Sedangkan kriteria yang digunakan dalam pemilihan komoditas unggulan ditunjukkan pada Tabel 5.

Tabel 5 Kriteria pemilihan komoditas

\begin{tabular}{|l|l|}
\hline \multicolumn{1}{|c|}{ Kriteria } & \multicolumn{1}{c|}{ Deskripsi } \\
\hline $\begin{array}{l}\text { Nilai } \\
\text { ekonomis }\end{array}$ & $\begin{array}{l}\text { Harga jual komoditas dan } \\
\text { potensi pasarnya }\end{array}$ \\
\hline $\begin{array}{l}\text { Basis } \\
\text { agroindustr } \\
\mathrm{i}\end{array}$ & $\begin{array}{l}\text { Volume komoditas yang telah } \\
\text { dimanfaatkan sebagai bahan } \\
\text { baku agroindustri pada wilayah } \\
\text { terpilih }\end{array}$ \\
\hline Bahan baku & $\begin{array}{l}\text { Volume dan kontinuitas } \\
\text { penyediaan komoditas }\end{array}$ \\
\hline $\begin{array}{l}\text { Peluang } \\
\text { produksi }\end{array}$ & $\begin{array}{l}\text { Potensi komoditas } \\
\text { dimanfaatkan oleh agroindustri }\end{array}$ \\
\hline $\begin{array}{l}\text { Diversifika } \\
\text { si }\end{array}$ & $\begin{array}{l}\text { Potensi komoditas untuk diolah } \\
\text { menjadi beragam produk olahan }\end{array}$ \\
\hline
\end{tabular}

Pemilihan komoditas unggulan di Kabupaten Tuban dilakukan dengan menilai setiap alternatif komoditas terhadap kriterianya. Penilaian dilakukan oleh dua orang narasumber ahli yang berasal dari instansi pemerintah. Hasil perhitungan yang diperoleh dengan menggunakan metode MPE ditunjukkan pada Tabel 6. Pada Tabel tersebut ditunjukkan bahwa komoditas ikan 
teri mempunyai nilai MPE yang paling tinggi dibandingkan lainnya. Berikutnya adalah ikan tembang dan rajungan, sedangkan rebon (udang kecil) mempunyai nilai MPE terendah. Berdasarkan nilai tersebut maka ikan teri mempunyai prioritas tertinggi untuk dikembangkan dan menjadi komoditas unggulan pada Kecamatan Palang.

Tabel 6 Hasil perhitungan pemilihan komoditas unggulan

\begin{tabular}{|l|c|c|}
\hline Alternatif Komoditas & Nilai MPE & Prioritas \\
\hline Ikan Tembang & 17537.06 & 2 \\
Ikan Teri & 46192.09 & 1 \\
Rebon & 9414.20 & 4 \\
Rajungan & 13416.27 & 3 \\
\hline
\end{tabular}

\section{Sub Model Produk Unggulan}

Alternatif produk unggulan yang akan dikembangkan adalah 1) ikan teri basah; 2) ikan teri asin kering; dan 3) balado ikan teri. Ketiga alternatif tersebut selanjutnya dipilih menggunakan lima kriteria sebagaimana ditunjukkan oleh Tabel 7.

Tabel 7 Kriteria pemilihan produk unggulan

\begin{tabular}{|l|l|}
\hline \multicolumn{1}{|c|}{ Kriteria } & \multicolumn{1}{c|}{ Deskripsi } \\
\hline $\begin{array}{l}\text { Peluang } \\
\text { Pasar }\end{array}$ & $\begin{array}{l}\text { Harga jual produk olahan dan } \\
\text { peluang pasarnya }\end{array}$ \\
\hline $\begin{array}{l}\text { Resiko } \\
\text { Produk }\end{array}$ & $\begin{array}{l}\text { Resiko kerusakan produk olahan } \\
\text { dan kestabilan harganya }\end{array}$ \\
\hline Teknologi & $\begin{array}{l}\text { Kemudahaan, fleksibilitas dan } \\
\text { nilai investasinya }\end{array}$ \\
\hline B/C ratio & $\begin{array}{l}\text { Perbandingan keuntungan total } \\
\text { dibandingan seluruh biaya yang } \\
\text { dikeluarkan }\end{array}$ \\
\hline $\begin{array}{l}\text { Dampak } \\
\text { Ganda }\end{array}$ & $\begin{array}{l}\text { Pengaruhnya terhadap aktivitas } \\
\text { usaha masyarakat di sekitar } \\
\text { seandainya agroindustri yang } \\
\text { dipilih dilksanakan }\end{array}$ \\
\hline
\end{tabular}

Hasil pemilihan dengan menggunakan metode Comparative Performance Indeks (CPI) disajikan pada Tabel 8.

Tabel 8 Hasil perhitungan CPI untuk pemilihan produk unggulan

\begin{tabular}{|l|c|c|}
\hline \multicolumn{1}{|c|}{ Produk Unggulan } & Nilai CPI & Prioritas \\
\hline Ikan Teri basah & 97.28 & $\mathbf{3}$ \\
Ikan Teri Asin Kering & 133.80 & $\mathbf{1}$ \\
Balado Teri & 130.97 & $\mathbf{2}$ \\
\hline
\end{tabular}

Pada Tabel 8 ditunjukkan bahwa produk unggulan yang terpilih untuk dikembangkan adalah ikan teri asin kering dengan nilai CPI 133.8. Prioritas kedua adalah balado teri dan berikutnya ikan teri basah. Berdasarkan obsevasi lapang, maka tersebut telah sesuai dengan realitas yang ada di wilayah pengembangan yang terpilih, yaitu Kecamatan Palang. Di wilayah tersebut jumlah produksi ikan terinya rata-rata $25.4 \%$ dari seluruh produksi perikanan. Jumlah agroindustri pengolahan teri asin kering skala kecil pada tahun 2005 adalah 36 unit atau 30\% dari jumlah agroindustri pengolahan teri asin di wilayah Kabupaten Tuban. Umumnya usaha tersebut masih menggunakan teknologi tradisional. Potensi tersebut menggambarkan bahwa produk ikan teri asin kering telah menjadi salah satu usaha pengolahan perikanan utama dan bagi masyarakat, walaupun pemasaran produknya masih bersifat lokal.

$$
y=a+b x+c x^{2}+d x^{3}+e x^{4}
$$

dimana :

$\begin{aligned} \mathrm{y} & =\text { Jumlah produksi ikan teri } \\ \mathrm{b} & =\text { Variabel waktu } \\ \mathrm{a} & =63.5735 \\ \mathrm{~b} & =2825.351 \\ \mathrm{c} & =-1049.4744 \\ \mathrm{~d} & =140.28042 \\ \mathrm{e} & =-6.080\end{aligned}$

Oleh karena berbagai parameter yang digunakan dalam penilaian berada dalam keadaan dinamis, maka dikembangkan empat skenario dalam analisis sensitivitas untuk menilai apakah dengan perubahan parameter-parameter tersebut agroindustri tetap layak dilaksanakan. Skenario yang dikembangan adalah sebagai berikut:

\begin{tabular}{|c|c|c|}
\hline Skenario A & $=$ & $\begin{array}{l}\text { Harga bahan baku } \\
\text { naik } 10 \% \text { dan harga } \\
\text { jual turun } 10 \%\end{array}$ \\
\hline Skenario B & $=$ & $\begin{array}{l}\text { Harga bahan baku } \\
\text { naik } 20 \% \text { dan harga } \\
\text { jual tetap }\end{array}$ \\
\hline Skenario C & $=$ & $\begin{array}{l}\text { Harga bahan baku } \\
\text { tetap dan harga jual } \\
\text { turun } 20 \%\end{array}$ \\
\hline Skenario D & $=$ & $\begin{array}{l}\text { Harga bahan baku } \\
\text { naik 20\%; harga jual } \\
\text { naik } 10 \% \text { dan harga } \\
\text { bahan bakar naik } \\
10 \%\end{array}$ \\
\hline Skenario E & $=$ & $\begin{array}{l}\text { Harga bahan baku } \\
\text { naik } 10 \% \text {; kondisi } \\
\text { lain tetap }\end{array}$ \\
\hline Skenario F & $=$ & $\begin{array}{lcr}\text { Harga } & \text { jual } & \text { turun } \\
10 \% ; & \text { kondisi } & \text { lain } \\
\text { tetap } & & \end{array}$ \\
\hline
\end{tabular}




\section{Sub Model Kelembagaan}

Berdasarkan hasil pengkajian yang mendalam, maka dapat dapat ditentukan komponen beserta hierarki sistemnya (Gambar 8). Struktur hierarki sistem kelembagaan terdiri dari dari atas empat jenjang. Jenjang pertama adalah aktor yang berperan dalam penentuan bentuk kelembagaan. Jenjang kedua adalah faktor yang dipertimbangkan dalam kelembagaan. Jenjang ketiga adalah tujuan yang mencerminkan keadaan yang akan dicapai melalui kelembagaan yang akan dipilih. Jenjang keempat adalah alternatif, yaitu bentuk-bentuk kelembagaan yang akan dipilih untuk pengembangan agroindustri. Nilai prioritas untuk seluruh komponen ditunjukkan Gambar 8.

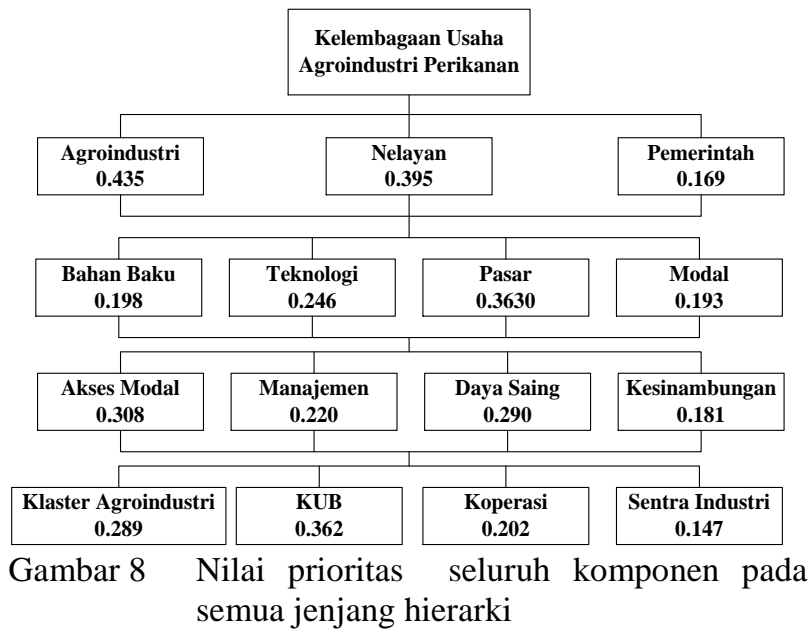

Berdasarkan nilai prioritasnya, pada jenjang pertama pelaku yang paling berperan dalam penentuan bentuk kelembagaan adalah agroindustri (43.5\%), berikutnya adalah nelayan $(39.5 \%)$ dan pemerintah (16.9\%). Peranan pemerintah paling rendah dibandingkan ketiga kedua pelaku lainnya. Hal ini menunjukkan bahwa inisiatif dalam membangun kelembagaan lebih banyak ditentukan oleh pelaku agroindustri sendiri dan nelayan, sedangkan pemerintah hanya berperan sebagai fasilitator

Pada jenjang kedua, faktor yang paling dipertimbangkan dalam penentuan kelembagaan adalah pasar (36.3\%), kemudian teknologi (24.6\%), berikutnya adalah bahan baku (19.8\%) dan yang terakhir adalah modal (19.3\%). Hasil tersebut menunjukkan bahwa kelembagaan harus mempertimbangkan kharakteristik dari usaha kecil yang sangat berbeda dari segi pasar, teknologi, pengadaan bahan baku dan modal usaha dibandingkan industri menengah atau besar

Pada jenjang ketiga, tujuan yang paling diprioritaskan dengan adanya kelembagaan ini adalah akses modal $(30.8 \%)$, daya saing $(29.0 \%)$, kemudahan manajeman $(22.0 \%)$ dan kesinambungan usaha $(18.1 \%)$. Hasil tersebut mempunyai arti bahwa kelembagaan yang dipilih harus mempunyai kemampuan untuk membuka akses permodalan bagi agroindustri skala kecil. Kelembagaan juga diharapkan dapat menjadi sarana bagi proses transformasi teknologi bagi agroindustri kecil agar kualitas produk yang dihasilkan meningkat dan mempunyai daya saing yang tinggi. Kelembagaan yang dipilih juga harus mampu memberikan keleluasaan dan kemudahan bagi para pelaku agroindustri skala kecil. Kompleksitas lembaga justru akan menyulitkan dan menghambat kinerja agroindustri. Prioritas terakhir adalah kemampuan kelembagaan untuk menjamin keberlangsungan usaha kecil terutama terhadap persaingan yang tidak sehat.

Bentuk kelembagaan yang paling sesuai bagi agroindustri skala kecil pada wilayah yang terpilih adalah Kelompok Usaha Bersama (KUB) (36.2\%), berikutnya adalah klaster agroindustri (28.9\%), koperasi $(20.2 \%)$ dan sentra industri (14.7\%). Kelompok usaha bersama merupakan bentuk penataan kelembagaan yang mendasarkan pada pola kerjasama bisnis antara keompok hulu (nelayan) dengan kelompok hilir (agroindustri). Tujuan utama KUB adalah mengintegrasikan aktivitas bisnis dan memberdayakan aset bersama sehingga proses transformasi teknologi, peluang pasar dan manajemen dapat berlangsung lebih efisien dan cepat. KUB dapat terdiri dari hanya beberapa pelaku kelompok hilir dan kelompok hulu yang menjalin kesepakatan bersama dalam usaha, akan tetapi KUB juga dapat dibentuk oleh banyak pelaku. Oleh karena itu struktur organisasi KUB bersifat fleksibel karena dapat disesuaikan dengan kemampuan anggota KUB. Bagi industri kecil kelembagaan ini diyakini dapat berjalan efektif karena KUB selain mempunyai tujuan bisnis, umunya juga dilandasi dengan sifat-sifat persaudaraan dan kekeluargaan.

\section{KESIMPULAN DAN SARAN}

\section{Kesimpulan}

Berdasarkan hasil kajian, maka dapat diambil beberapa kesimpulan, antara lain sebagai berikut:.

a. Investasi agroindustri perikanan diperlukan dalam rangka mengotimalkan pemanfaatn sumberdaya perikanan, menumbuhkan 
dan mengembangkan agroindustri perikanan.

b. Ketersediaan sumberdaya perikanan dan keberlangsungan agroindustri perikanan skala kecil perlu diperhatikan dalam perencanaan investasi pada suatu wilayah. Oleh karena itu diperlukan kebijakan pemerintah yang mengatur tentang tingkat investasi agroindustri.

c. Model penunjang keputusan investasi dikembangkan dalam bentuk Sistem Manajemen Ahli dengan menggunakan pendekatan wilayah. Model tersebut terdiri dari enam sub model, yaitu sub model wilayah pengembangan agroindustri, sub model komoditas perikanan unggulan, sub model produk unggulan, sub model potensi bahan baku, sub model kelayakan finansial dan sub model kelembagaan.

d. investasi agroindustri dengan kapasitas produksi 1 ton bahan baku ikan teri per hari adalah layak. Hasil verifikasi menunjukkan bahwa kelembagaan usaha yang sesuai bagi pengembangan agroindustri pengolahan ikan teri asin skala kecil adalah Kelompok Usaha Bersama (KUB).

\section{Saran}

Kajian yang diperlukan dalam rangka mengembangkan model SMA investasi adalah sebagai berikut:

a. Membangun model dinamis untuk mengkaji jumlah produksi ikan teri.

b. Aplikasi model yang dikembangkan dengan spreadsheet Microsoft Excel dirasakan masih mempunyai banyak keterbatasan, terutama untuk jaringan interface dan penyimpanan data. Oleh karena itu perlu dikembangkan program aplikasi yang berbasis bahasa komputasi tertentu agar kinerja sistem dapat lebih optimal dan fleksibel.

\section{DAFTAR PUSTAKA}

Austin JE. 1992. Agroindustrial Project Analysis. Critical Design Factors. EDI Series in Economic Development. Baltimore and London : The John Hopkins University Press.

BAPPENAS. 2004. Tata Cara Perencanaan Pengembangan Kawasan untuk Percepatan Pembangunan Daerah. Jakarta: Badan Perencanaan Pembangunan Nasional.

Bodie Z. Kane A. Markus AJ. 2005. Investment Six Edition. Mc. New York: Mc. Graw Hill. Companies Incorporation.

Dahuri R. 2003. Paradigma Baru Pembangunan Indonesia Berbasis Kelautan [orasi ilmiah]. Bogor: FPIK IPB.
DKP. 2004. Revitalisasi Perikanan. Jakarta: Dinas Kelautan dan Perikanan.

Diskanlut Kabupaten Tuban. 2012. Laporan Tahunan. Dinas Perikanan dan Kelautan Kabupaten Tuban.

Eriyatno. 1999. Ilmu Sistem: Meningkatkan Mutu dan Efektifitas Manajemen. Bogor:

IPB Press.

Fauzi A. 2002. Evaluasi Status Keberlanjutan Pembangunan Perikanan: Aplikasi Metode Rapfish. Jurnal Pesisir dan Lautan. 4 (3).

Gittinger JP. 1986. Analisis Ekonomi Proyek-proyek Pertanian. Jakarta: UI-Press-Johns Hopkins.

Hanafiah. 1998. Pendekatan Wilayah dalam Pembangunan Pedesaan. Bogor: Jurusan Ilmu Sosial Ekonomi Pertanian IPB.

Harris JM. 2001. A Survey of Sustainable Development: Social and Economic Dimensions. The Global Development and Enviroment. Washington, Covelo, London: Institute Tufts University Island Press.

Harta M. Barton J. 2007. Balancing Local Ownership with Foreign Investment in a Small Island Island Fishery. Ocean \& Coastal management. 50.

Hartono TT. Nasution Z. 2005. Aspekaspek Sosial Budaya dalam Kerangka Upaya Pemberdayaan masyarakat Nelayan di Indonesia. Jurnal Penelitian Perikanan Indonesia. Edisi Sosial Ekonomi. 11 (3).

Kadariah. 1986. Evaluasi Proyek: Analisa Ekonomi. Edisis Dua. Jakarta: Lembaga Penerbit Fakultas Ekonomi-UI.

Kementrian Kelautan dan Perikanan. 2004. Investment Opportunities. Jakarta: Ministry of Marine Affairs and Fisheries Republic of Indonesia.

Kusumadewi K. 2002. Analisis dan desain Sistem Fuzzy Menggunakan Tool Box Matlab. Jakarta: Graha Ilmu.

Kusumastanto T. 1994. An Investment Strategy for the Development of Brackiswater Shrimp Aquaculture 
Industry in Indonesia [disertation]. Alabama: Auburn University.

Ma'arif MS dan Tandjung. 2003. Teknik-teknik Kuantitatif untuk Manajemen. Jakarta: PT Gramedia Widiasarana Indonesia.

Marimin. 2004. Teknik dan Aplikasi Pengambilan Keputusan Kriteria Majemuk. Jakarta: Grasindo.

Marimin. 2005. Teori dan Aplikasi Sistem Pakar dalam Teknologi Manajerial. Bogor: IPB Press.

Mardle S dan Pascoe S. 2002. Use of Evolutionary Methods for Bioeconomic Optimization Models: An Application to Fisheries. Agriculture System. 66.

Montgomery DC. 1991. Design and Analysis of Experiments $\left(3^{\text {rd }}\right)$. New York Chichester Brisbane Toronto Singapure : John Wiley \& Sons.

Murillas A. Chamorro JM. 2006. Valuation and Management of Fishing Resources under Price Uncertainty. Journal Environmental \& Resources Economic. 33. 